\title{
Hniezdne spoločenstvá vtákov vo vzt’ahu k štruktúre urbánneho prostredia malého mesta (Sabinov, východné Slovensko)
}

\author{
Breeding bird communities in relation to structure of urban \\ environment of a small town (Sabinov, E Slovakia)
}

\section{Miroslav Fulín ${ }^{1}$, Stanislav Greš ${ }^{2}$, Peter Krišovský $\mathrm{SNR}^{3}$, Tomáš MIŠEK ${ }^{4}$ \& Benjamín JARČUŠKA ${ }^{5}$}

\author{
${ }^{1}$ Puškinova 15, 08301 Sabinov, Slovensko; e-mail: miro.fulin@gmail.com \\ ${ }^{2}$ Ul. 17. novembra 24, 08301 Sabinov, Slovensko \\ ${ }^{3}$ Murgašova 8, 08301 Sabinov, Slovensko \\ ${ }^{4}$ Puškinova 1, 08301 Sabinov, Slovensko \\ ${ }^{5}$ Ústav ekológie lesa SAV, L. Štúra 2, 96001 Zvolen, Slovensko; e-mail: benjamin.jarcuska@gmail.com
}

\begin{abstract}
In the present study, we explored the effects of urban habitat attributes on richness, density and community composition of breeding birds. We performed the study during breeding season within a small town (c. 12,000 inhabitants) in eastern Slovakia in 2019. We assessed bird data and habitat characteristics for seven zones (town centre, an old detached houses' residential area, a recent detached houses' residential area, industrial zone, a high-rise buildings' residential area, greenway) within the study area (347 ha). We found 40 breeding species and 2,033 breeding pairs within the area. The bird species were classified into six nesting guilds (building-nesters, hole-nesters, tree-crown-nesters, shrub-nesters, ground-nesters, and riparian cavity-nesters) and to four groups with different affinity to urban environment. The building-nesters were the most abundant guild followed by treecrown-nesters. We found that maximum tree height and ruderal vegetation cover correlated positively with overall species richness, and maximum number of buildings' floors correlated positively with overall abundance (per 10 ha). Abundance of hole-nesters, tree-crown-nesters and shrub-nesters correlated positively with tree cover, and negatively with cover of hard surfaces; building-nesters' abundance was positively correlated with maximum number of buildings' floors. Tree cover and maximum number of buildings' floors explained 50.7\% of species composition in zones. Composition of nesting guilds differed between the town zones. Our results indicate the importance of urban vegetation to maintain higher breeding bird species richness in town environment.
\end{abstract}

Key words: bird communities, habitat, species richness, urban ecology, temperate zone

\section{Úvod}

Celosvetovo žije v mestách pokrývajúcich menej než $3 \%$ povrchu súše viac ako polovica ludskej populácie (Aronson et al. 2014). Obdobne je to aj na Slovensku: v mestách žije viac ako polovica populácie krajiny (ŠÚ SR 2019). V 11 najludnatejších slovenských mestách žije okolo 1,3 milióna obyvatel'ov
(25\% populácie Slovenska) (ŠÚ SR 2019). Očakáva sa, že podiel mestského obyvatel'stva bude $\mathrm{v}$ budúcnosti d'alej stúpat' a teda že dôjde aj k zvýšeniu výmery miest (Seto et al. 2012). Urbanizácia ma priamy negatívny vplyv na pôvodné habitaty a ich flóru a faunu (MacGregor-Fors 2008), súčasne vytvára nové unikátne habitaty (Sandström et al. 2006, Beninde et al. 2015, Lepczyk et al. 2017), čo 
sa odzrkadl'uje v zložení spoločenstiev rastlín a živočíchov. Globálne sa udáva, že v mestách žije menej druhov vtákov na jednotku plochy než v neurbanizovanej krajine (Sandström et al. 2006, MacGregor-Fors 2008, Aronson et al. 2014, Lepczyk et al. 2017) avšak ich početnost' býva vyššia (Chace \& Walsh 2006, Lepczyk et al. 2017). Všeobecne má urbanizácia negatívny vplyv na vzácne a špecializované druhy vtákov; druhy ekologicky všestranné a flexibilné dokážu v urbanizovanom prostredí úspešne existovat' (Sol et al. 2014). Dôvodom synantropizácie niektorých vtáčích druhov býva napr. vyššia ponuka hniezdnych príležitostí, vyššia potravná ponuka $\mathrm{v}$ mestách v zime, vyššia teplota, nižšia miera predácie dospelých vtákov alebo dlhšia vegetačná sezóna (Gil \& Brum 2014). Pôdny kryt (,land cover") najlepšie vysvetl'uje druhovú bohatost' vtákov na jednotku plochy v mestách na globálnej úrovni (Aronson et al. 2014). Na úrovni sídel sa často sleduje vplyv gradientu urbanizácie, v smere od centra mesta ku jeho okraju, na charakteristiky biodiverzity, avšak tento zjednodušený prístup neodhal'uje priamy vplyv faktorov podmieňujúcich biodiverzitu urbánneho prostredia (Beninde et al. 2015).

Pri spravovaní života v meste je dôležité, aby orgány samosprávy poznali nielen demografické údaje o obyvatel'och ale aj charakteristiky zložiek životného prostredia. Zmeny v charaktere bývania, úprave vonkajšieho prostredia, vnášanie nových architektonických prvkov do intravilánu mesta sa čoraz viac prejavujú „odprírodnením“ v myslení obyvatel'ov. Pre živočíšne druhy v tomto prostredí vznikajú i zanikajú potravné i reprodukčné možnosti. Zelené plochy v mestách však nie sú dôležité len z pohl'adu podpory biodiverzity, ale aj z aspektu duševného a telesného zdravia a pohody človeka (Louv 2008, Daniš 2016). Vtáky môžu slúžit' ako indikačné druhy kvality habitatov nielen v mestách (Sandström et al. 2006, MacGregorFors 2008). Poznanie súčasného zloženia a stavu živočíšnych a rastlinných spoločenstiev a ich nárokov pomôže kompetentným úradom lepšie pri územnom plánovaní a manažmente rôznych aktivít $\mathrm{v}$ sídlach a tak predchádzat' porušovaniu legislatívnych noriem pri spolunažívaní človeka s nimi.

Na Slovensku sú práce zamerané na kompletné posúdenie ornitocenóz mestských oblastí vel'mi ojedinelé (napr. Jambor 2020). Ak sú takéto spoločenstvá popísané, tak ich autori konštatujú nejednotnost' v kategorizácií jednotlivých sídelných celkov (Urbanová \& Kocian 1997) a z toho vyplývajúcu problematickost' pri porovnávaní s inými lokalitami. Častejšie sú popisované iba vybraté biotopy v mestách, napr. parky (Kropil 2002), cintoríny (Karaska 2002, Mošanský \& Pačenovský 2014). Pri viacerých druhoch sa stretávame iba s konštatovaním, že druh žije aj synantropne (napr. Darolová \& Krištín 2002). Ornitocenózy vidieckych osídlení študovali napr. aj Salaj (1971, 1989) a Šolomeková (2008).

V snahe zabezpečit' prvotný obraz o stave avifauny v meste Sabinov sme sa rozhodli zmapovat' spoločenstvá vtáčích druhov v hniezdnej sezóne v roku 2019. Druhovú bohatost' a početnost' hniezdiacich druhov vtákov, aj vybraných hniezdnych gíld, hodnotíme vo vzt'ahu k charakteristikám urbánneho prostredia. Výsledkom je správa o zložení hniezdnej populácie v intraviláne mesta ako aj poznámky a návrhy na zachovanie či zlepšenie jej súčasného stavu.

\section{Materiál a metodika}

\section{Študované územie}

Mesto Sabinov sa nachádza na severovýchod-

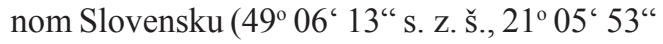
v. z. d.). Rozprestiera sa v údolí rieky Torysa v nadmorskej výške 320 m n. m. Priemerná ročná teplota je $7,8{ }^{\circ} \mathrm{C}$, priemerná januárová teplota je $-4,5^{\circ} \mathrm{C}$ a priemerná júlová teplota je $18,4^{\circ} \mathrm{C}$. Teplotné maximá $\left(35\right.$ a $\left.36^{\circ} \mathrm{C}\right)$ boli zaznamenané v mesiacoch júl a august. Priemerný ročný úhrn zrážok je 618 mm. Priemerný počet dní so snehovou pokrývkou okolo $25 \mathrm{~cm}$ je 70 dní. Prevládajúcim vetrom je severozápadný vietor. Hydrologicky patrí Sabinov do povodia 
Hornádu (Michaeli 2000). Hranica študovaného územia (obr. 1, 2) prebieha zväčša okrajom zastavaného územia mesta, jej juhozápadnú čast' tvorí rieka Torysa a na východe potok Telek, ktorý toto územie oddel'uje od mestskej časti Orkucany. Študované územie susedí na juhozápade so zmiešanými lesnými porastami (vek zväčša nad 100 rokov, zloženie: borovica lesná, borovica čierna, smrekovec, hrab obyčajný, buk lesný, dub zimný, http://gis.nlcsk.org/ lgis/), inde je obklopené pol'nohospodárskou krajinou. Študované územie má rozlohu 3,75 $\mathrm{km}^{2}$, v najdlhšom smere dosahuje dížku $3,5 \mathrm{~km}$ a v najužšom mieste má $0,6 \mathrm{~km}$. Na území mesta aj s pričlenenými mestskými čast'ami (mimo študované územie) žije 12413 obyvatel'ov (k 31. 11. 2017; Anonymus 2020).

\section{Habitatová charakteristika intravilánu mesta}

Pre účely mapovania vtáctva sme intravilán mesta rozdelili na 7 zón líšiacich sa ich využitím a charakterom zástavby a vegetácie (obr. 1, 2):

1. Centrum mesta (rozloha 44 ha): Začína železničnou stanicou a cez väznicu, evanjelické kostoly siaha až po gréckokatolícky kostol. V tejto časti zlepšuje biodiverzitu prostredia park na Murgašovej ulici. Tvorí ho areál so smutnými vŕbami, ginkom dvojlaločným, lipou malolistou. Lemovaný je po celom obvode udržiavaným živým plotom. Na ulici Kpt. Nálepku pred evanjelickými kostolmi je rad líp malolistých. V strede historickej časti mesta je šošovkovité námestie v centrálnej časti s parkom. Vegetáciu parku tvoria vysoké, cca 80

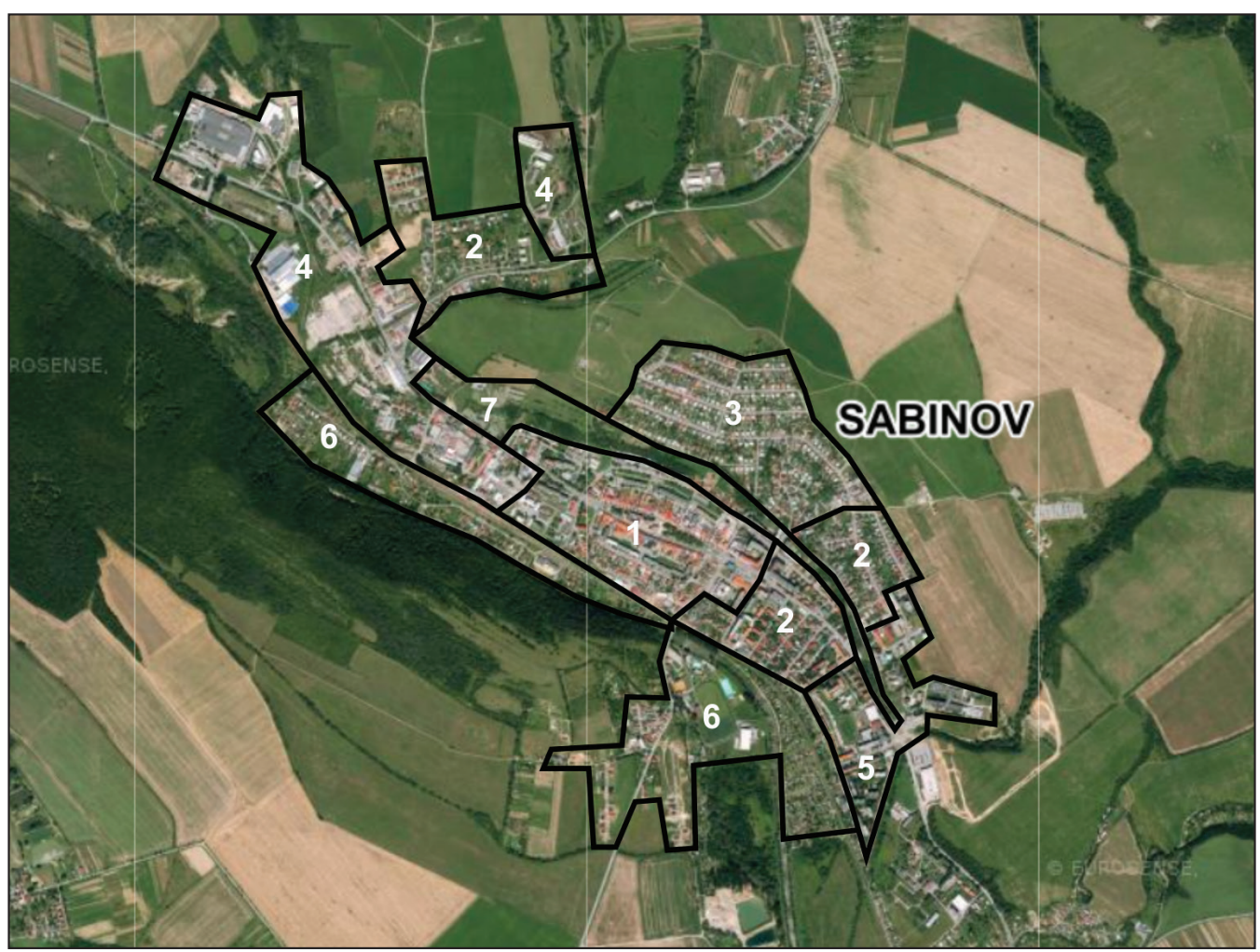

Obr. 1. Študovaná čast' mesta Sabinov s hranicami siedmich monitorovaných zón: 1 = centrum mesta, 2 = rodinné domy z 50. -90 . rokov minulého storočia, 3 = rodinné domy od 90 . rokov minulého storočia po súčasnost', $4=$ priemyselná čast', 5 = sídlisko, 6 = záhradky a športový areál, 7 = pás zelene. Podkladová mapa: mapy.cz, ( Seznam.cz.

Fig. 1. Studied part of town Sabinov with boundaries of seven surveyed zones: $1=$ town centre, $2=$ an old detached houses' residential area (50s -90 s of the $20^{\text {th }}$ century), $3=$ a recent detached houses' residential area (since 90 s of the $20^{\text {th }}$ century to present), 4 = industrial zone, 5 = a high-rise buildings' residential area, $6=$ gardening settlement and sports area, $7=$ greenway. Background map: mapy.cz, () Seznam.cz. 

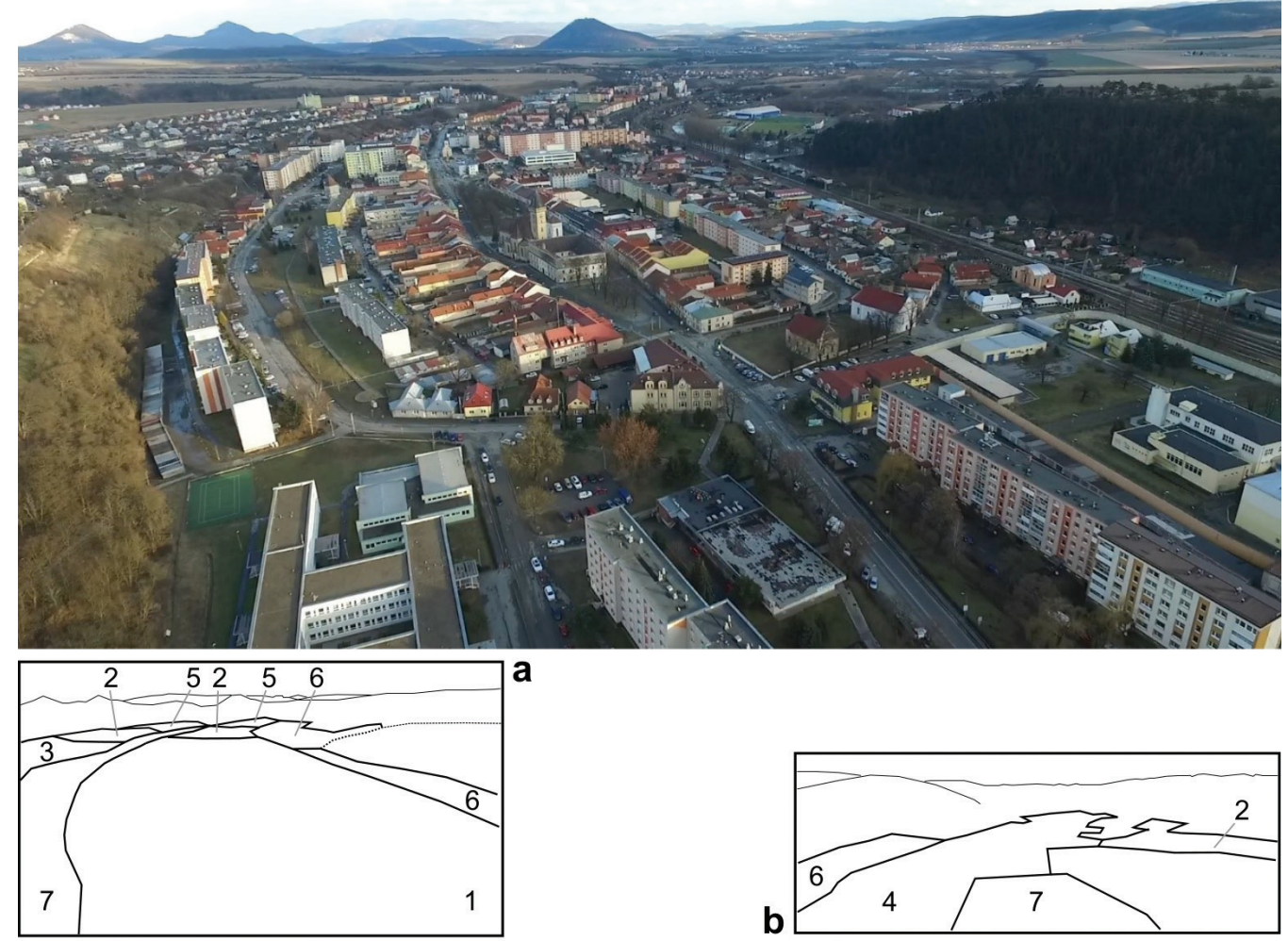

a

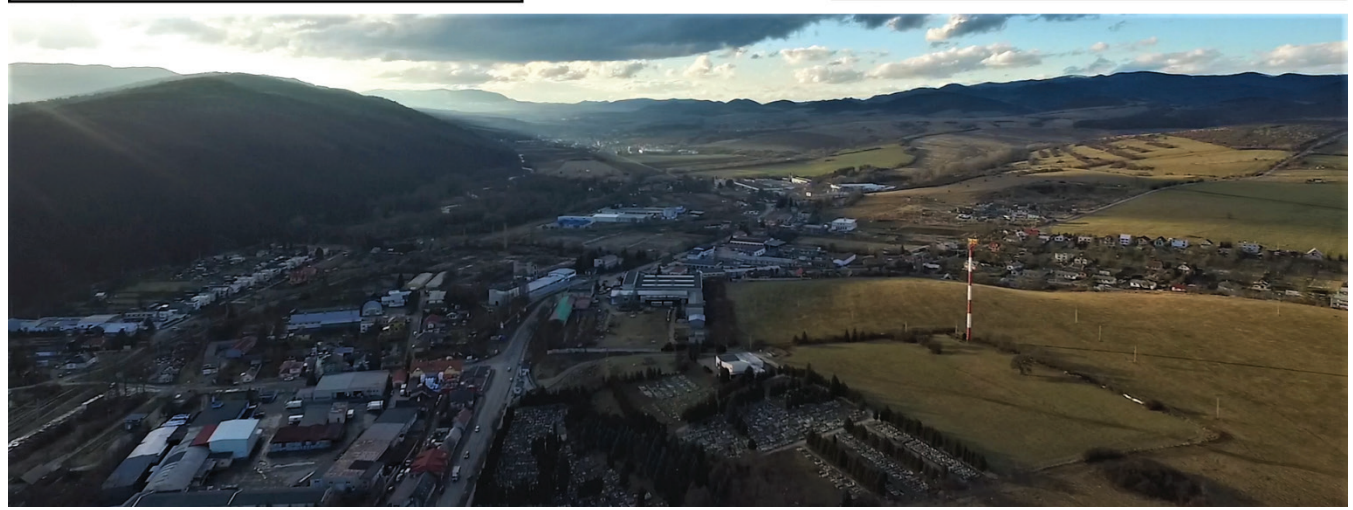

Obr. 2. Pohl'ad na východnú (a) a západnú (b) čast' mesta s monitorovanými zónami $1-7$ (obr. 1). Foto: J. Ščavnický.

Fig. 2. View of an eastern part (a) and a western (b) part of the town with surveyed zones 1-7 (Fig. 1). Photo by J. Ščavnický.

a viac rokov staré stromy pagaštanu konského, lipy malolistej. Nad ním šošovkovité námestie uzatvárajú opät' stromy parku. Po oboch stranách historického námestia vedú hlavné cestné komunikácie. V parku sa nachádza fontána. Vnútorný priestor mesta uzatvára radová zástavba historic- kých meštianskych domov na námestí s dlhými dvormi smerom von $\mathrm{z}$ námestia. $\mathrm{V}$ súčasnosti sú tieto dvory prestavané novodobými prvkami na účelové stavby. Po ich vonkajšom obvode prebiehajú po oboch stranách súbežne s centom mesta komunikácie obojstranne lemované starý- 
mi domami. Do tohto priebehu štruktúry mesta bola v 80. rokoch zakomponovaná výstavba pät’podlažných panelových bytoviek, ktorá tvorí akúsi hradbu. Vonkajší okraj centra mesta v južnej časti ukončuje ešte radová zástavba starších rodinných domov lemovaná železničnou trat'ou, 7 a 9 podlažné panelové bytovky, nákupné centrum a Mestské kultúrne stredisko. Severnú hranicu centra mesta tvoria panelové bytovky na Ulici 17. novembra a areál Základnej školy.

2. Celok rodinných domov z 50. - 70. rokov 20. storočia (rozloha 55 ha): V južnej časti mesta ho tvoria tehlové trojpodlažné bytovky a rodinné domy. Do priestoru spadá aj areál so smrekom pichl'avým, brezou, smrekom obyčajným a živým plotom pred ZŠ na ul. 9. mája. Ďalším priestorom takéhoto typu sú rodinné domy na Ovocinárskej ulici v severnej časti mesta. Charakteristické sú pre tento celok obytné domy, záhrady so staršími ovocnými stromami a živými plotmi. Doplňujúcimi prvkami sú záhradné domčeky, altánky a garáže. Na časti Prešovskej ulice je tento charakter prerušený sedempodlažnou panelovou bytovkou.

3. Rodinné domy postavené v 90 . rokoch 20. storočia až po súčasnost' (rozloha 42 ha): Celok predstavuje hustá zástavba rodinných domov; jedná sa o radovú zástavbu. Charakteristické pre tento celok je, že boli postavené na pol'nohospodársky využívanej pôde bez existujúcej vzrastlej vegetácie. Zeleň, ktorá sa tu nachádza V súčasnosti má charakter ozdobnej zelene, živých plotov alebo je len vo forme nízkych ovocných stromov.

4. Priemyselný areál (rozloha 92 ha): Areály pôvodných závodov (Frucona, sklad dreva štátnych lesov) sú dnes opustené, resp. prechádzajú prestavbou a na ich plochách dnes vznikajú depónie stavebného materiálu alebo sú to ladom ležiace pozemky. Ostatné priemyselné areály (Sanas, Milkagro a iné) sú zastavané administratívnymi, technicko-prevádzkovými, skladovými budovami a výrobnými halami $\mathrm{s}$ komunikáciami $\mathrm{v}$ areáloch bez stromovej zelene. V smere na Drienicu je areál hospodárskeho dvora pol'nohospodárskeho družstva zameraného na chov hovädzieho dobytka.
5. Sídlisko (rozloha 25 ha): Komplex samostatných starších tehlových a novších panelových bytoviek s areálom základnej školy na Komenského ulici v juhovýchodnej časti mesta. V priestore sa nachádzajú vtrúsené zachovalé pôvodné staršie stromy verejnej zelene a ovocné stromy. Podobný komplex bez pôvodnej vegetácie vznikol medzi Poliklinikou a potokom Telek, v ktorom vystupuje aj komplex Združenej strednej školy.

6. Športový areál a záhradky (rozloha 68 ha): V južnej časti mesta za riekou Torysa vystupuje športový areál s kúpaliskom. Významným parkovým prvkom je tu porast šl'achtených topol'ov na brehu Torysy v Kocurparku a líp pri Mestskom kúpalisku. Na tento celok nadväzujú záhrady a obytné domy medzi železničnou trat'ou a riekou Torysa. Na charakter biotopu tu má podstatný vplyv bezprostrednost' lesného celku Švabl'ovka a rieka Torysa. Záhradkárska osada Medzi vodami po potok Telek je pokračovaním tohto biotopu južným smerom.

7. Biokoridor na svahu riečnej terasy (rozloha 21 ha): Od kruhovej križovatky na Prešovskej ulici pri potoku Telek vystupuje svah pôvodnej riečnej terasy. Tiahne sa celým mestom. V priestore medzi Puškinovou ulicou a ulicou SNP existuje viacero výverov vôd s možnost'ou pitia a kúpania sa vtákov. Miestami je tento priestor husto porastený krovitou a stromovou vegetáciou, na iných miestach ho tvoria záhrady so stromovou vegetáciou pri rodinných domoch. Tento celok je ukončený mestským cintorínom, na ktorom sa nachádzajú pôvodné i nepôvodné druhy stromov. Nad cintorínom vystupuje opustený ovocný sad so staršími, málo zachovalými drevinami s dutinami. Tento biotop má miestami charakter lesa.

\section{Mapovanie hniezdiacich vtákov}

Mapovanie hniezdneho rozšírenia vtáčích druhov sme realizovali v mesiacoch apríl - máj 2019 od skorých ranných hodín a počas celého dňa. Ciel'om prieskumu bolo zmapovat' teritóriá vtáčích druhov podl'a prejavov svedčiacich o ich hniezdení počas prvého hniezdenia v roku. Postupovali sme podl'a štandardných stupňov 
a kategórií na dokazovanie preukaznosti hniezdenia používaných pri mapovaní do Európskeho atlasu hniezdiacich vtákov (EBBA 2; Bejček \& Št’astný 2014), všetky údaje sme zaznamenávali do databázy Aves (SOS/BirdLife Slovensko). Za dôkaz hniezdenia a teda prítomnosti hniezdiaceho páru sme považovali teritoriálne správanie sa samcov v čase hniezdenia, prinášanie hniezdneho materiálu, stavbu hniezda, prinášanie potravy na hniezdo, sedenie na násade a kŕmenie mlád'at na hniezde. Pokial' to podmienky umožňovali, vstupovali sme do všetkých dostupných priestorov v meste, prešli sme všetkými komunikáciami v meste. Areály závodov a nám nedostupné priestory sme monitorovali spoza oplotenia pomocou d'alekohl'adu. Mapovanie sme realizovali nezávisle od seba po tej istej trase opakovane, získané výsledky (t.j. nálezy hniezd a hniezdne teritóriá) zaznamenávali do mapy a na záver sme ich vzájomne prehodnotili a určili konečný stupeň preukaznosti hniezdenia. Prihliadali sme aj na špecifické správanie sa jednotlivých druhov a v prípade pochybnosti, dokladovali sme ich hniezdenie počas celého hniezdneho obdobia dohl'adaním hniezdnej stavby. Súčast’ou nálezu hniezda bol aj zápis o hniezdnom stanovišti pre účely praktického využitia dát pre ochranu druhu.

Zaznamenané hniezdiace druhy sme podl'a najčastejšieho miesta umiestnenia hniezda zaradili do piatich skupín - hniezdnych gíld: hniezdič na l'uských stavbách (St), v korunách stromov $(\mathrm{Sm})$, v kríkoch $(\mathrm{Kr})$, v dutinách stromov $(\mathrm{Du})$, na zemi či v bylinnom poraste $(\mathrm{Zm})$ a v dutinách a výčnelkoch rôzneho pôvodu na brehoch vôd (Sk) (príloha 1). Niektoré druhy boli zaradené súčasne do viacerých gíld. Druhy boli do gíld zaradené prevažne na základe vlastných poznatkov a publikovaných zdrojov (napr. Št’astný \& Hudec 2011).

Podl'a väzby vtáčích druhov na urbánne prostredie sme vtáky zaradili na základe vlastných poznatkov do štyroch skupín. Prvú kategóriu tvoria druhy, ktoré sú silne potravne aj hniezdením viazané na človeka a jeho obydlie. Druhú kategóriu tvoria vtáčie druhy, ktoré sú viazané na človeka a ním vytvorený priestor z hl'adiska hniezdneho habitatu. Potravne sú na intraviláne závislé iba sekundárne. Tretiu kategóriu tvoria druhy, ktoré využívajú ponúkané možnosti na hniezdenie v blízkosti človeka a aj existujúce výhody l'ahšieho zisku potravy a tiež druhy (väčšinou lesné druhy), ktorým biotopy $\mathrm{v}$ intraviláne (park, cintorín, opustené plochy) pripomínajú pôvodný biotop. Štvrtú skupinu tvoria druhy, ktoré bežne v urbanizovanom prostredí nehniezdia (príloha 1).

V spracovaných výsledkoch prinášame pre správu mesta aj ekonomické vyjadrenie spoločenstva vtáčích druhov podl'a spoločenskej hodnoty vtákov (Príloha č. 32 k Vyhláške MŽP SR č. 24/2003 Z. z.).

\section{Stanovenie habitatu v zónach mesta}

Leteckú snímku územia (https://sk.mapy.cz/s/ dezuvopole; 14. 12. 2019) sme náhodne preložili siet'ou $20 \times 20 \mathrm{~m}$. Bodové siete by mali byt' $\mathrm{v}$ heterogénnom prostredí vhodnejšie než

Tab. 1. Charakteristika zón mesta Sabinov. Pre zóny pozri obr. 1.

Table 1. Characteristics of Sabinov town zones. For zones see Fig. 1.

\begin{tabular}{|c|c|c|c|c|c|c|c|c|c|c|c|}
\hline \multirow[b]{2}{*}{$\frac{\stackrel{0}{5}}{\stackrel{0}{N}}$} & \multicolumn{8}{|c|}{ Pokryvnost' / Ground cover (\%) } & \multirow[b]{2}{*}{ 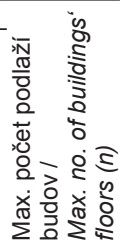 } & \multirow[b]{2}{*}{ 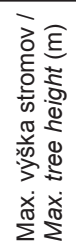 } & \multirow[b]{2}{*}{ 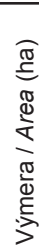 } \\
\hline & 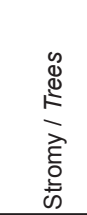 & $\frac{n}{\frac{n}{2}} \frac{1}{5}$ & 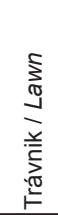 & 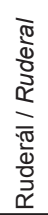 & 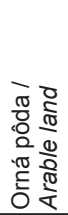 & 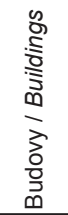 & 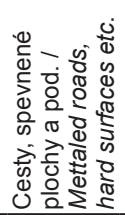 & \begin{tabular}{l}
$\frac{1}{d}$ \\
\multirow{\pi}{J}{} \\
$\frac{\pi}{0}$ \\
$\frac{0}{>}$
\end{tabular} & & & \\
\hline 1 & 9,6 & 0,9 & 18,4 & 0,0 & 0,9 & 38,6 & 31,6 & 0,0 & 7 & $\overline{16}$ & 44 \\
\hline 2 & 21,6 & 0,0 & 35,2 & 0,8 & 2,4 & 23,2 & 16,8 & 0,0 & 7 & 12 & 55 \\
\hline 3 & 17,3 & 0,0 & 25,0 & 0,0 & 10,6 & 30,8 & 16,3 & 0,0 & 2 & 6 & 42 \\
\hline 4 & 10,7 & 0,7 & 18,6 & 8,6 & 0,0 & 25,7 & 35,7 & 0,0 & 2 & 22 & 92 \\
\hline 5 & 12,5 & 1,1 & 29,5 & 0,0 & 1,1 & 22,7 & 33,0 & 0,0 & 9 & 9 & 25 \\
\hline 6 & 20,8 & 0,7 & 26,4 & 4,2 & 9,7 & 17,4 & 18,8 & 2,1 & 2 & 20 & 68 \\
\hline 7 & 52,8 & 5,7 & 32,1 & 0,0 & 5,7 & 3,8 & 0,0 & 0,0 & 5 & 12 & 21 \\
\hline
\end{tabular}


plochy, ked’že zachytia väčšiu množinu rôznych habitatov (napr. DeMeo et al. 2013). V každej zóne mesta sme na tejto sieti náhodne vybrali línie a na nich 53 - 144 priesečníkov siete (počet sa líšil v závislosti od vel'kosti a heterogenity zóny). Habitat na priesečníkoch sme zaradili do jednej z vopred definovaných kategórií a vypočítali ich relatívnu pokryvnost' (pôdny kryt) v zóne. Zist'ovali sme tieto charakteristiky habitatu: pokryvnost' stromov, krov, udržiavaných trávnatých plôch (trávnikov v parkoch a okolo bytových domov, trávnych porastov v záhradách; d’alej „trávnikov“), ruderálnej vegetácie (neobhospodarovanej trávnatej a bylinnej vegetácie), obhospodarovanej pôdy (záhradky), budov, spevnených plôch (cesty, chodníky, parkoviská, dvory a pod.) a vodných plôch (tab. 1). Ďalej sme zistili maximálny počet nadzemných podlaží na budovách v zóne a maximálnu výšku stromov v zóne (odhadom s presnost'ou $\pm 1-2 \mathrm{~m}$ ).

\section{Analýza údajov}

Analýzy sa urobili v prostredí štatistického programu R (R Core Team 2019). Na stanovenie vzt'ahu medzi relatívnou pokryvnost'ou zón typom habitatu, maximálnym počtom nadzemných podlaží a maximálnou výškou stromov v zónach vo väzbe na celkovú druhovú bohatost' a hustotu populácií hniezdiacich vtákov (v prepočte na $10 \mathrm{ha}$ ) a na druhovú bohatost' a hustotu hniezdnych gíld a skupín druhov s rôznou väzbou na urbánny habitat sme použili Spearmanovu koreláciu $\left(\mathrm{r}_{\mathrm{s}}\right)$. Ak bol druh zaradený do viacerých hniezdnych gíld súčasne, tak sa pri korelačnej analýze ponechal len v jednej a to najčastejšej, najtypickejšej, prípadne najbezpečnejšej z pohl'adu ochrany pred predáciou. Vzt'ahy medzi premennými boli zobrazené pomocou funkcie, ,ggscatter" z knižnice, ggpubr“ (Kassambara 2019). Vzhl'adom na malú vel'kost' vzorky ( $n=7$ zón) a jej možný negatívny vplyv na P-hodnoty (a silu testov) sme pre $r_{s}$ medzi charakteristikami prostredia a charakteristikami populácií hniezdiacich vtákov vypočítali aj $95 \%$ konfidenčný interval (CI) (Nakagawa \& Cuthill 2007) pomocou funkcie „spearman.ci“ z knižnice „RVAideMemoire“ (Hervé 2019).
Zloženie spoločenstiev v študovaných zónach vo vzt'ahu k charakteristikám prostredia sme analyzovali pomocou redundančnej analýzy založenej na vzdialenostiach (Distance-Based Redundancy Analysis; dbRDA) implementovanú v knižnici „,vegan“ (Oksanen et al. 2018) - funkcia „capscale“. Zloženie spoločenstiev vtákov sme charakterizovali pomocou Bray-Curtisovej matice nepodobnosti. Druhovú početnost' (na 10 ha) sme transformovali dekadickým logaritmom $\left(\log _{10} \mathrm{x}+1\right)$. Ak boli environmentálne premenné vzájomne silno korelované $\left(\mathrm{r}_{\mathrm{s}}>0,7\right.$; Dormann et al. 2013), tak sme ako vysvetl'ujúcu premennú použili len jednu z danej dvojice premenných. Funkcie „ordistep“ a ,ordiR2step“ sme použili na identifikovanie najvýznamnejších vysvetl'ujúcich premenných. Permutačný test s 200 neobmedzenými permutáciami sme použili na otestovanie štatistickej významnosti vysvetl'ujúcich premenných.

\section{Výsledky a diskusia}

\section{Druhová bohatost' a početnost'}

V študovanom území intravilánu mesta Sabinov sme v roku 2019 zaznamenali hniezdenie 2033 párov 40 vtáčích druhov (príloha 1). V jednotlivých zónach mesta sa druhová bohatost' pohybovala v rozmedzí 19 - 31 druhov. Počet hniezdiacich párov sa $\mathrm{v}$ jednotlivých zónach pohyboval od 21,8 po 177,7 p./10 ha. Najpočetnejšími zaznamenanými druhmi boli dážd'ovník obyčajný (Apus apus) a belorítka obyčajná (Delichon urbicum) (>9 p./10 ha; príloha 1$)$. K dominantným druhom ( $\geq 5 \%$ ) patrili aj drozd čierny (Turdus merula), žltochvost domový (Phoenicurus ochruros), vrabec domový (Passer domesticus) a drozd čvíkota (Turdus pilaris). Dvadsat' druhov malo dominanciu vyššiu než cca $1 \%$ z celkovej hniezdnej populácie (D\%), 27 druhov malo hustotu nižšiu než 1 p./10 ha (príloha 1). Tri zaznamenané druhy sú druhmi európskeho významu (bocian biely (Ciconia ciconia), d'atel' hnedkavý (Dendrocopos syriacus) a strakoš obyčajný 
(Lanius collurio)) a tiež 3 sú druhmi národného významu (krutohlav hnedý (Jynx torquilla), muchár sivý (Muscicapa striata), pŕhl'aviar čiernohlavý (Saxicola rubicola); Vyhláška č. 24/2003 Z. z.). Počet druhov vtákov hniezdiacich $v$ mestskom prostredí pozitívne súvisí s heterogenitou jeho prostredia (Melles et al. 2003, Ferenc et al. 2016); tá zväčšsa pozitívne koreluje s výmerou územia (Freemark \& Merriam 1986, Ferenc et al. 2014a). Napr. v urbánnom prostredí Trenčína na ploche 23,6 ha zistil Jambor (2020) 32 druhov hniezdičov (2009 - 2019); Macháčová (2016) a Sychra et al. (2016) zistili v celom katastrálnom území Brna $\left(230 \mathrm{~km}^{2}\right) 136$ druhov hniezdičov (z toho 109 dokázaných), obdobne i v Sofii - 133 hniezdičov $/ 230 \mathrm{~km}^{2}$ (Iankov 2005), v Prahe bolo na 496 km² zistených 125 druhov hniezdiacich vtákov (Fuchs et al. 2002). Nami zaznamenaná hodnota hustoty hniezdičov v zóne s najvyšším podielom stromov (cca $50 \%$; príloha 1 ) bola totožná s tými $\mathrm{v}$ prírodných lesných habitatoch - listnatých lesoch (napr. Danko et al. 2010, Pčola 2012).

Viacero druhov hniezdilo vo viacerých kategóriách umiestnenia hniezda; $v$ tom prípade tu uvádzame počet druhov hniezdičov typických pre danú gildu a v zátvorke celkový počet druhov aj s druhmi hniezdiacimi najmä na iných miestach. Hniezdenie na budovách a technických zariadeniach vybudovaných v meste sme zistili u 11 druhov vtákov (príloha 1). V korunách stromov hniezdilo 8 (10) druhov; 7 (9) druhov hniezdilo v kríkoch (a živých plotoch); 8 druhov hniezdilo v dutinách stromov; 4 (6) druhy na zemi alebo $\mathrm{v}$ bylinnom poraste a 1 (2) druhy v dutinách a výčnelkoch rôzneho pôvodu na brehoch vôd. Počtom hniezdiacich párov bola najviac zastúpená gilda hniezdičov na stavbách (1077p.), nasledovaná gildou hniezdičov v korunách stromov (409 p.) a krov (374 p.), v stromových dutinách (142 p.) a nakoniec na zemi a v bylinách (21 p.) a v dutinách a výčnelkoch rôzneho pôvodu na brehoch vôd (1 p.; príloha 1, tab. 2). Vtáky v centrách európskych miest hniezdia najčastejšie na budovách a/alebo v stromových dutinách (40 \%), na zemi
(35\%), stromových dutinách (30\%) a $25 \%$ v kríkoch (Jokimäki et al. 2016a).

$Z$ registrovaných druhov boli zistené 3 druhy s najsilnejšou väzbou na urbánne prostredie - hrdlička záhradná (Streptopelia decaocto), vrabec domový a žltochvost domový (345 p.; príloha 1). V druhej kategórii, kde urbánne prostredie slúži vtákom ako hniezdny habitat, bolo zaznamenaných 7 druhov a 724 p. (napr. dážd’ovník obyčajný, belorítka obyčajná, lastovička obyčajná (Hirundo rustica)). Tretiu skupinu druhov, ktoré využívajú urbanizované prostredie mesta a ním ponúkané hniezdne i potravné možnosti, no nie sú na neho primárne odkázané, tvorilo 21 druhov (894 p.), napr. drozd čierny, drozd čvíkota, stehlík obyčajný (Carduelis carduelis). Štvrtú kategóriu druhov, ktoré v urbánnom prostredí bežne nehniezdia, tvorilo 9 druhov a 65 p., napr. vrabec polný (Passer montanus), strnádka obyčajná (Emberiza citrinella), pŕhl'aviar čiernohlavý (príloha 1). Obdobná druhová skladba bola zistená aj v iných európskych sídlach, najmä v podobných habitatoch (vid' napr. Urbanová \& Kocian 1997, Kelcey \& Rheinwald 2005, Jokimäki et al. 2016a, b, Macháčová 2016, Jambor 2020). Spoločenstvá vtákov miest naprieč Európou sú relatívne uniformnejšie v porovnaní so spoločenstvami z okolitej, vol'nej krajiny, čo svedčí o homogenizácii spoločenstiev vtákov vplyvom urbanizácie na kontinentálnej úrovni (Ferenc et al. 2014a). Zaujímavé je, že v Sabinove sme ako hniezdiče nezaznamenali holuba hrivnáka (Columba palumbus) a dokonca ani ferálneho holuba skalného (Columba livia f. domestica). Hrivnák je pôvodne lesným druhom, ktorý prenikol do miest najprv v západnej Európe (od začiatku 19. storočia; Wesołowski \& Fuller 2012) a koncom minulého storočia aj na Slovensku (napr. Navrátilová \& Trnka 2016). Vo Fínsku boli väčšie mestá kolonizované skôr než menšie (Fey et al. 2015). Ferálny holub skalný v minulosti hniezdil na veži rímsko-katolíckeho kostola v centre Sabinova (cca. maximálne dvadsat' jedincov), dnes tomu tak už nie je. 

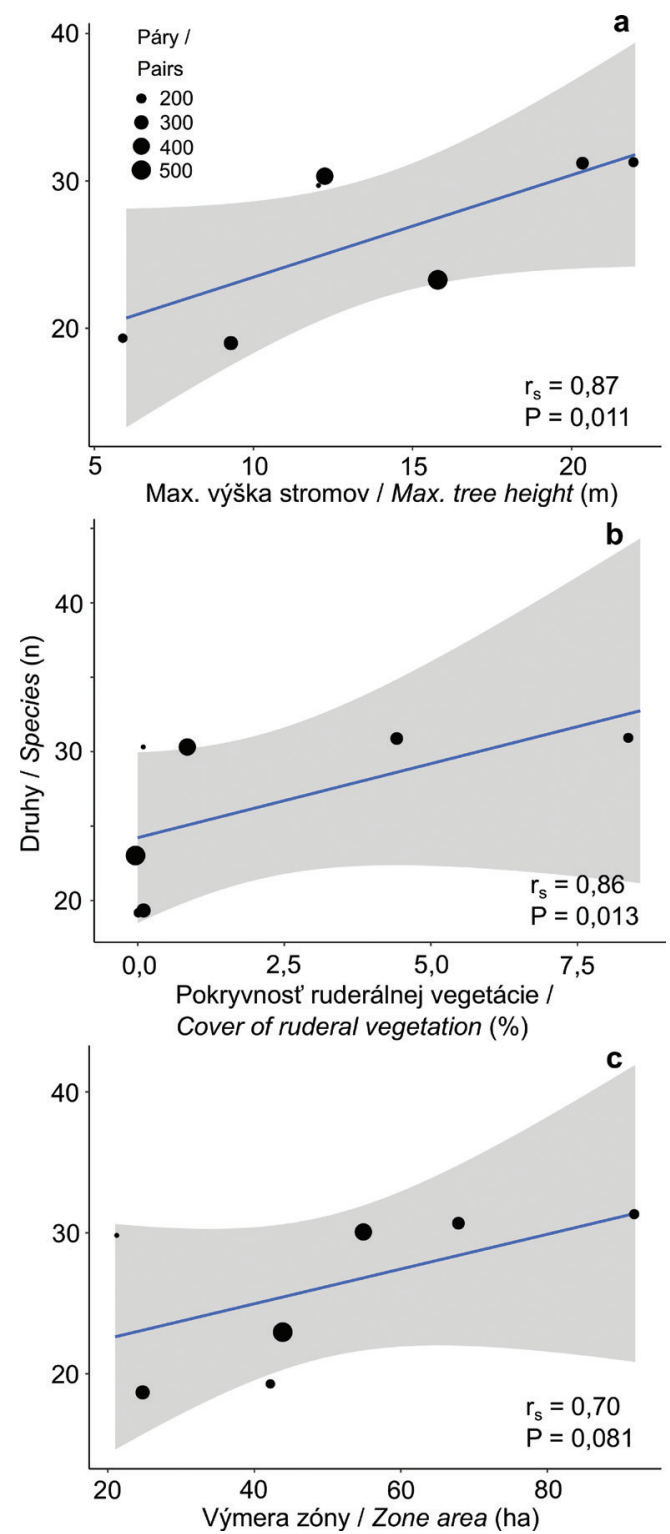

Obr. 3. Graf lineárnej regresie pokryvnosti ruderálnej vegetácie (a), maximálnej výšky stromov (b), a výmery zóny (c) vo vzt’ahu k počtu hniezdiacich druhov vtákov v mestskej zóne. Zobrazený je aj 95 \% konfidenčný interval regresnej priamky. Fig. 3. Linear regression plots of cover of ruderal vegetation (a), maximum tree height (b), and zone area (c) in relation to the number of breeding bird species in the town zone. 95\% confidence limits for regression line are shown.

\section{Vplyv habitatu na druhovú bohatost',}

početnost' a spoločenstvá vtákov

Pokryvnost' stromov v zónach bola významne korelovaná s pokryvnost'ou trávnikov $\left(\mathrm{r}_{\mathrm{s}}=0,86\right.$,
$\mathrm{P}=0,014)$ a spevnených plôch $\left(\mathrm{r}_{\mathrm{s}}=-0,79, \mathrm{P}=\right.$ 0,036); pokryvnost' obhospodarovanej pôdy s pokryvnost'ou spevnených plôch $\left(\mathrm{r}_{\mathrm{s}}=-0,79\right.$, $\mathrm{P}=0,036)$ a pokryvnost' ruderálnych plôch $\mathrm{s}$ maximálnou výškou stromov $\left(\mathrm{r}_{\mathrm{s}}=0,77, \mathrm{P}=\right.$ 0,045); príloha 2.

Druhová bohatost' v zóne pozitívne korelovala $\mathrm{s}$ maximálnou výškou stromov $\left(\mathrm{r}_{\mathrm{s}}=0,87\right.$, $\mathrm{CI}=0,40-1,00, \mathrm{P}=0,011$; obr. 3a). Vyššie (a teda aj hrubšie) stromy poskytujú viac potravných aj hniezdnych ník, čo môže podporit' hniezdny výskyt širšej škály druhov (Melles et al. 2003, MacGregor-Fors 2008). Maximálna výška stromov bola silne korelovaná s pokryvnost'ou ruderálnej vegetácie (vid' vyššie), ktorá môže zvyšovat' heterogenitu prostredia, preto by sa ich vplyv na druhovú bohatost' tu nedal odseparovat' (Dormann et al. 2013). Pokryvnost' ruderálnej vegetácia s druhovou bohatost'ou korelovala pozitívne $\left(\mathrm{r}_{\mathrm{s}}=0,86, \mathrm{CI}=0,53-1,00\right.$, $\mathrm{P}=0,013$; obr. $3 \mathrm{~b})$. Vegetačné charakteristiky (napr. pokryvnost', štruktúra, podiel plôch zelene, hustota stromov, krovín) majú všeobecne silne pozitívny vplyv na druhovú diverzitu (bohatost' a abundanciu) vtákov v mestách (Evans et al. 2009, Aronson et al. 2014, Ferenc et al. 2014b, 2016, Beninde et al. 2015, Tryjanowski et al. 2017). Porovnávanie vel'kosti vplyvu environmentálnych (habitatových) premenných na charakteristiky vtáčích spoločenstiev urbanizovaného prostredia naprieč lokálnymi prípadovými štúdiami môže byt' zavádzajúce vzhl'adom na to, že vel'kost' $R^{2}$ závisí aj od zaznamenaného rozptylu vysvetl'ujúcej premennej v danej štúdii (Nakagawa \& Cuthill 2007). Metaanalýzou 75 štúdií najmä z Európy a Severnej Ameriky sa identifikovali plochu habitatu a prítomnost' koridorov spájajúcich dve plochy s rovnakým habitatom ako faktory s najväčším vplyvom na biodiverzitu sídel celkovo a osobitne vtáctva, nasledované štruktúrou vegetácie (Beninde et al. 2015). Lokálne, biotické a manažmentové faktory boli významnejšie než faktory na úrovni krajiny, abiotické a geografické charakteristiky miesta (Beninde et al. 2015).

Druhová bohatost' bola pozitívne korelovaná aj s výmerou zón $\left(\mathrm{r}_{\mathrm{s}}=0,70, \mathrm{CI}=-0,16-\right.$ 


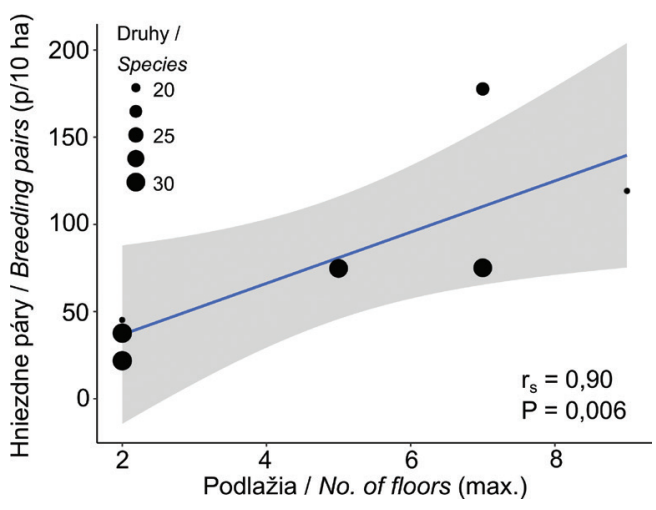

Obr. 4. Graf lineárnej regresie maximálneho počtu nadzemných podlaží budov vo vzt'ahu k počtu párov hniezdiacich druhov vtákov v mestskej zóne. Zobrazený je aj $95 \%$ konfidenčný interval regresnej priamky.

Fig. 4. Linear regression plot of maximum number of aboveground floors in buildings in relation to the number of breeding bird pairs in the town zone. 95\% confidence limits for regression line are shown.

$1,00, P=0,081$; obr. $3 \mathrm{c}$ ), najsilnejšie pri počte druhov hniezdičov na stavbách $\left(\mathrm{r}_{\mathrm{s}}=0,74, \mathrm{CI}=\right.$ $0,06-1,00, \mathrm{P}=0,057)$ a v kríkoch $\left(\mathrm{r}_{\mathrm{s}}=0,73, \mathrm{CI}\right.$ $=-0,06-0,99, \mathrm{P}=0,063$; vid' nižšie). Vel'kost' plochy je všeobecne významnou premennou vplývajúcou kladne na druhovú bohatost' vtákov nielen v mestách (Evans et al. 2009, Beninde et al. 2015, Ferenc et al. 2016). Zaznamenaný počet hniezdiacich párov (na 10 ha) pozitívne koreloval s maximálnym počtom nadzemných podlaží stavieb v zóne $\left(\mathrm{r}_{\mathrm{s}}=0,90, \mathrm{CI}=0,43-\right.$ $1,00, \mathrm{P}=0,006$; obr. 4). Súvisí to s vysokou početnost'ou belorítky a dážd'ovníka $\mathrm{v}$ zónach s viacpodlažnými budovami, ktoré týmto druhom slúžia na hniezdenie (napr. Matisová et al. 2015).

Druhová bohatost' druhov najmä hniezdením naviazané na urbánny habitat (kategória 2, príloha 1) negatívne korelovala s podielom obrábanej pôdy $\left(\mathrm{r}_{\mathrm{s}}=-0,76, \mathrm{CI}=-1,00-0,06, \mathrm{P}\right.$ $=0,046) \mathrm{a}$ ich početnost' pozitívne korelovala s maximálnym počtom nadzemných podlaží stavieb $\left(\mathrm{r}_{\mathrm{s}}=0,88, \mathrm{CI}=0,41-1,00, \mathrm{P}=0,009\right)$. Hniezdna početnost' druhov hniezdiacich v urbanizovanom prostredí aj vol'nej krajine (kategória 3) korelovala s pokryvnost'ou stro$\operatorname{mov}\left(r_{s}=0,86, C I=0,09-1,00, P=0,014\right)$ a spevnených plôch $\left(\mathrm{r}_{\mathrm{s}}=-0,96, \mathrm{CI}=-1,00-\right.$

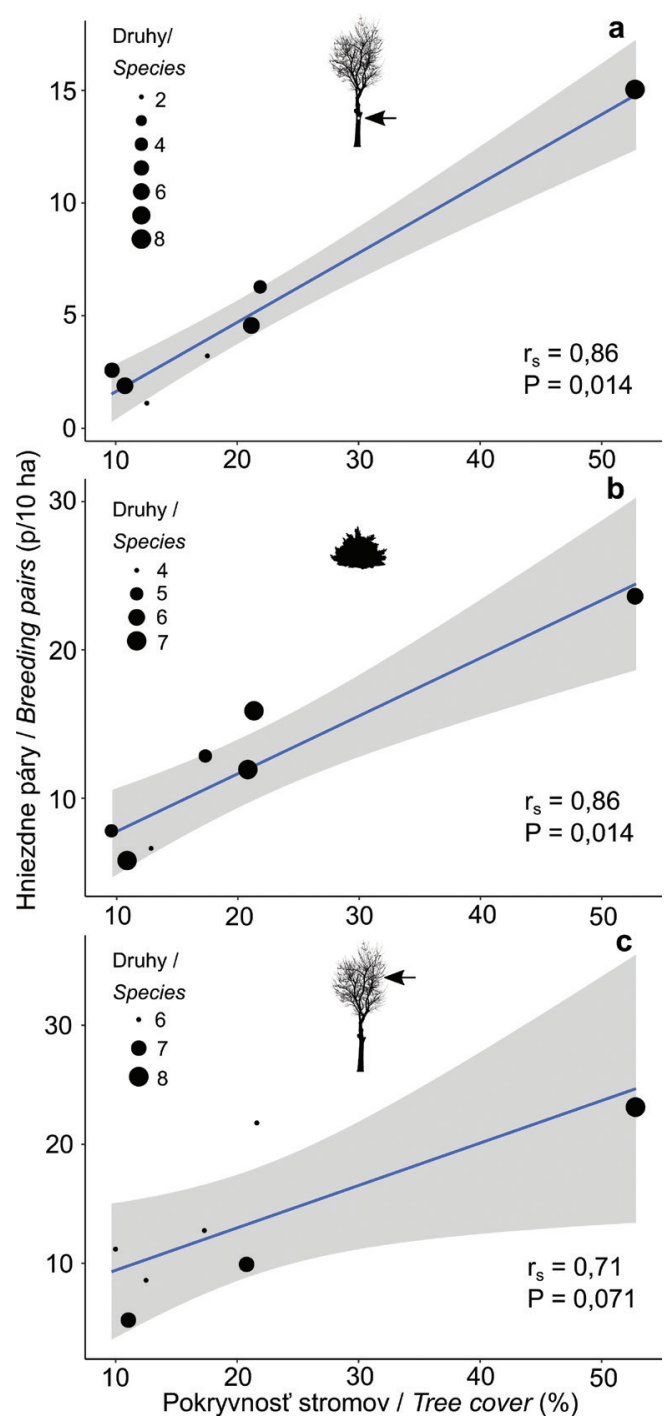

Obr. 5. Graf lineárnej regresie pokryvnosti stromov vo vztahu k počtu hniezdnych párov dutinových hniezdičov (a), hniezdičov v kríkoch (b) a v korunách stromov (c) v mestskej zóne. Zobrazený je aj 95 \% konfidenčný interval regresnej priamky. Fig. 5. Linear regression plots of tree cover in relation to the number of breeding bird pairs of cavity nesters (a), shrubnesters (b), and tree-crown-nesters (c) in the town zone. 95\% confidence limits for regression line are shown.

$-0,41, \mathrm{P}<0,001)$. Počet druhov, ktoré bežne v urbanizovanom prostredí nehniezdia (kategória 4), pozitívne koreloval s podielom ruderálnej vegetácie $\left(\mathrm{r}_{\mathrm{s}}=0,80, \mathrm{CI}=0,21-1,00, \mathrm{P}=0,030\right)$ a s maximálnou výškou stromov $\left(\mathrm{r}_{\mathrm{s}}=0,77, \mathrm{CI}\right.$ $=0,00-1,00, \mathrm{P}=0,043)$. 
Tab. 2. Hniezdne gildy v zónach mesta. Pre zóny pozri obr. 1.

Table 2. Nesting guilds in city zones. For zones see Fig. 1.

\begin{tabular}{|c|c|c|c|c|c|c|c|c|}
\hline \multicolumn{8}{|c|}{ Hniezdna gilda / Nest guild } & $\Sigma$ \\
\hline \multicolumn{9}{|c|}{ Hniezdiče na stavbách (St) / Building-nesters } \\
\hline páry / pairs & 424 & 169 & 69 & 72 & 257 & 66 & 20 & 1077 \\
\hline p./10 ha & 96,4 & 30,7 & 16,4 & 7,8 & 102,8 & 9,7 & 9,5 & 31,0 \\
\hline druhy / species & 7 & 11 & 5 & 8 & 7 & 7 & 4 & 11 \\
\hline \multicolumn{9}{|c|}{ Hniezdiče v korunách stromov (Sm) / Tree-crown-nesters } \\
\hline páry / pairs & 48 & 120 & 53 & 49 & 22 & 68 & 49 & 409 \\
\hline p./10 ha & 10,9 & 21,8 & 12,6 & 5,3 & 8,8 & 10,0 & 23,3 & 11,8 \\
\hline druhy / species & 6 & 6 & 6 & 7 & 6 & 7 & 8 & 8 \\
\hline \multicolumn{9}{|c|}{ Hniezdiče v kríkoch (Kr) / Shrub-nesters } \\
\hline páry / pairs & 34 & 87 & 53 & 54 & 16 & 81 & 49 & 374 \\
\hline p./10 ha & 7,7 & 15,8 & 12,6 & 5,9 & 6,4 & 11,9 & 23,3 & 10,8 \\
\hline druhy / species & 5 & 7 & 5 & 7 & 4 & 7 & 6 & 7 \\
\hline \multicolumn{9}{|c|}{ Dutinové hniezdiče (Du) / Hole-nesters } \\
\hline páry / pairs & 12 & 35 & 13 & 16 & 3 & 32 & 31 & 142 \\
\hline p./10 ha & 2,7 & 6,4 & 3,1 & 1,7 & 1,2 & 4,7 & 14,8 & 4,1 \\
\hline druhy / species & 5 & 4 & 2 & 6 & 2 & 6 & 8 & 8 \\
\hline \multicolumn{9}{|c|}{ Hniezdiče na zemi či v bylinnom poraste $(\mathrm{Zm})$ / Ground-nesters } \\
\hline páry / pairs & 0 & 2 & 2 & 5 & 0 & 7 & 5 & 21 \\
\hline p./10 ha & 0,0 & 0,4 & 0,5 & 0,5 & 0,0 & 1,0 & 2,4 & 0,6 \\
\hline druhy / species & 0 & 2 & 1 & 3 & 0 & 3 & 3 & 4 \\
\hline \multicolumn{9}{|c|}{ Druhy hniezdiace v dutinách a výčnelkoch rôzneho pôvodu pri vodných tokoch (Sk) / Riparian cavity-nesters } \\
\hline páry / pairs & 2 & 5 & 1 & 5 & 1 & 6 & 0 & 20 \\
\hline p./10 ha & 0,5 & 0,9 & 0,2 & 0,5 & 0,4 & 0,9 & 0,0 & 0,6 \\
\hline druhy / species & 1 & 1 & 1 & 1 & 1 & 2 & 0 & 2 \\
\hline
\end{tabular}

Počet párov dutinových hniezdičov, vtákov hniezdiacich v korunách stromov či krov bol pozitívne korelovaný s pokryvnost'ou stromov (dutiny: $\mathrm{r}_{\mathrm{s}}=0,86, \mathrm{CI}=-0,09-1,00, \mathrm{P}=0,014$; kry: $\mathrm{r}_{\mathrm{s}}=0,86, \mathrm{CI}=0,35-1,00, \mathrm{P}=0,014$; koruny stromov: $r_{s}=0,71, \mathrm{CI}=-0,17-1,00$, $\mathrm{P}=0,071$; obr. $5 \mathrm{a}-\mathrm{c})$, respektíve negatívne s podielom spevnených plôch (dutiny: $r_{\mathrm{s}}=$ $-0,86, \mathrm{CI}=-1,00--0,37, \mathrm{P}=0,014 ;$ kry: $\mathrm{r}_{\mathrm{s}}=$ $-0,96, \mathrm{CI}=-1,00--0,68, \mathrm{P}<0,001$; koruny stromov: $\mathrm{r}_{\mathrm{s}}=-0,93, \mathrm{CI}=-1,00--0,68, \mathrm{P}=$ 0,003). Početnost' párov hniezdiacich v kríkoch korelovala s pokryvnost'ou stromov, nie však samotných kríkov. To môže byt' spôsobené metodikou vzorkovania habitatu (vid' vyššie), ked' sme kríky nemuseli zachytit' napr. kvôli ich rastu pod korunami stromov, prípadne pre úzky kolmý priemet živých plotov. Druhová bohatost' hniezdičov v kríkoch bola korelovaná s podielom ruderálnej vegetácie $\left(\mathrm{r}_{\mathrm{s}}=0,87, \mathrm{CI}=\right.$ $0,64-0,97, \mathrm{P}=0,012)$. Na ruderalizovaných plochách (v priemyselnej zóne Sabinova a na okraji záhradkárskej osady) je väčšia možnost' pre rast krov väčších rozmerov než v iných zónach. Rovnako, ako pri celkovej početnosti hniezdiacich párov (vid' vyššie), aj početnost' párov druhov hniezdiacich na stavbách korelovala s maximálnym počtom nadzemných podlaží $\left(\mathrm{r}_{\mathrm{s}}=0,80, \mathrm{CI}=-0,06-1,00, \mathrm{P}=0,029\right)$, ked'že táto hniezdna gilda bola v skúmanom území najpočetnejšia čo do počtu hniezdiacich párov (príloha 1). Relatívna pokryvnost' krov alebo trávnikov korelovala s druhovou bohatost'ou alebo početnost'ou hniezdičov slabšie (kry: $\mathrm{r}_{\mathrm{s}}=|0,02-0,52|, \mathrm{P}=0,21-0,97$; trávnik: $\left.r_{s}=|0,00-0,64|, P=0,11-1,00\right)$, to môže byt' metodickým artefaktom spôsobeným malým zaznamenaným rozpätím hodnôt ich pokryvnosti (tab. 1) a vel'kost'ou vzorky (n= 7 zón). Všeobecne platí, že malá vel'kost' vzorky súvisí so širokými konfidenčnými intervalmi testovanej charakteristiky a teda nižšou presnost'ou či spol'ahlivost'ou výsledkov (Nakagawa \& Cuthill 2007), v našom prípade silou korelácie, preto by bolo vhodnejšie zist'ovat' charakteristiky vtáčích spoločenstiev aj habitatu na väčšej vzorke.

Zloženie spoločenstiev hniezdičov sa líšilo medzi jednotlivými zónami (príloha 1, tab. 2, obr. 6). Pokryvnost' stromov a počet podlaží vysvetlili $50,7 \%$ variability spoločenstiev (db-RDA, $\mathrm{P}<0,03$ ). Druhy svojim hniezdením viazané na budovy boli najpočetnejšie $\mathrm{v}$ centre mesta a na sídlisku, v zónach, kde je najviac viacpodlažných bytových domov (obr. 1, zóny 1 a 5). Druhy hniezdiace v korunách stromov či kríkov boli relatívne najpočetnejšie v bioko- 


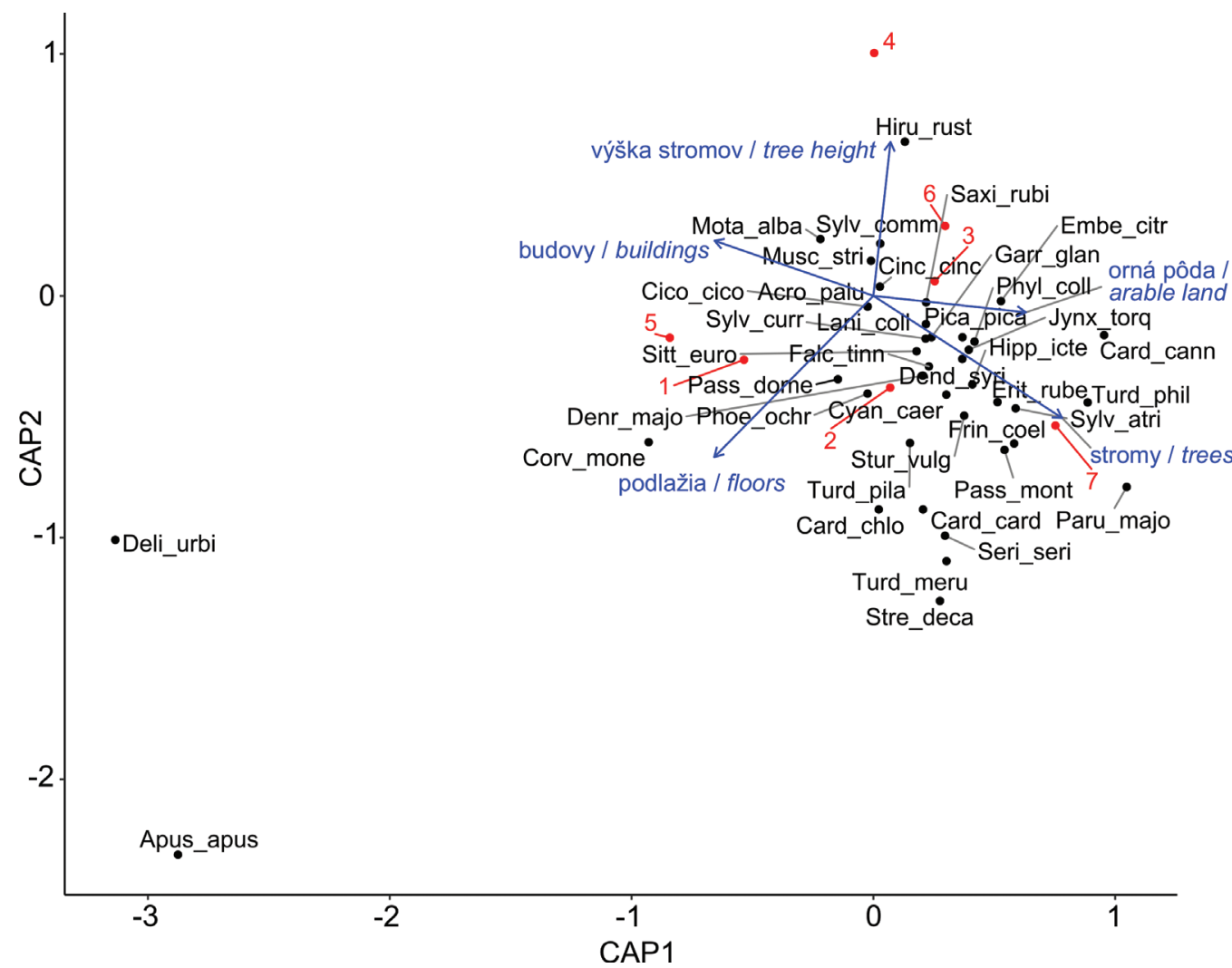

Obr. 6. Redundančná analýza založená na vzdialenostiach (dbRDA) vzt’ahu medzi druhovým zložením spoločenstiev vtákov a charakteristikami siedmych mestských zón Sabinova (1 -7, obr. 1). Škála predstavuje hodnoty Bray-Curtisovej nepodobnosti $\log _{10} x+1$-transformovanej druhovej početnosti. Skratky mien vtákov sú zložené s prvých štyroch písmen rodových a druhových vedeckých mien. Výška stromov = maximálna výška stromov, orná pôda = pokryvnost' ornej pôdy, stromy = pokryvnost' stromov podlažia = maximálny počat podlaží, budovy = pokryvnost' budov.

Fig. 6. Distance-based Redundancy Analysis (dbRDA) of the association between species composition of bird communities and characteritics of seven Sabinov town zones (1-7, Fig. 1). The scale represents the Bray-Curtis dissimilarities of $\log _{10} x+1$ transformed species adundances. The abbreviations of the species names are composed of the first four letters of the genus and species scientific names. Tree height $=$ maximum tree height, arable land $=$ cover of arable land, trees $=$ cover of trees, floors = maximum number of buildings' floors, buildings $=$ cover of buildings .

ridore (zóna 7) a v zóne s rodinnými domami z polovice minulého storočia (zóna 2). Dutinové hniezdiče dosahovali najvyšších hustôt v zóne s najvyšším podielom stromov, tam boli najpočetnejšie aj druhy hniezdiace na zemi alebo v bylinnej vegetácii (zóna 7).

\section{Záver}

Mapovaním hniezdnej populácie vtáčích druhov v intraviláne Sabinova sme potvrdili prítomnost' 40 vtáčích druhov. $Z$ tohto počtu považujeme
10 druhov za charakteristických hniezdičov intravilánu mesta - napr. dážd’ovník obyčajný, belorítka obyčajná, žltochvost domový, vrabec domový, hrdlička záhradná. Tieto druhy pravidelne a dlhodobo využívajú intravilán mesta ako svoje hniezdne teritórium (príloha 1 - väzba na intravilán 1 a 2). Celkovo, najpočetnejšie bol zastúpený dážd'ovník obyčajný, nasledovaný belorítkou obyčajnou, žltochvostom domovým a drozdom čiernym. Na úrovni siedmych zón vytýčených na území mesta Sabinov, líšiacich sa charakteristikami habitatu, sme zistili koreláciu medzi druhovou bohatost'ou, početnost'ou 
druhov, rovnako aj bohatost'ou a početnost'ou hniezdnych gíld a niekol'kými sledovanými charakteristikami. Vyšší relatívny podiel vegetácie v zónach pozitívne koreloval s druhovou bohatost'ou hniezdiacich vtákov celkovo (ruderálna vegetácia) alebo početnost'ou jednotlivých hniezdnych gíld (stromy), podobne s počtom druhov hniezdičov pozitívne korelovala aj maximálna výška stromov. Maximálny počet podlaží pozitívne koreloval s početnost'ou druhov celkovo, aj s početnost'ou druhov hniezdiacich na stavbách. Možno preto očakávat', že podpora heterogénnej zelene v mestách, ochrana dutinových stromov alebo alternatívne rozvešiavanie hniezdnych búdok bude mat' pozitívny vplyv aj na druhovú bohatost' a početnost' hniezdiaceho vtáctva; na potreby druhov hniezdiacich na budovách treba preto tiež prihliadat' (Ferenc et al. 2014b, 2016, Jokimäki et al. 2018).

Spoločenská hodnota hniezdiacich párov predstavovala sumu 1062890 Eur (bez započítania ich potomstva).

\section{Opatrenia na zachovanie a zlepšenie súčasného stavu}

Na základe uvedených zistení o hniezdnej populácii vtáčích druhov v meste Sabinov pre zachovanie a zlepšenie jej stavu je potrebné prijat' tieto opatrenia:

- pri ošetrovaní prestarnutých stromov dbat' na zachovanie prirodzených dutín pre hniezdenie vtáčích druhov,

- pri výrube starých stromov s dutinami nahrádzat' ich ponukou umelých dutín vo forme vtáčích búdok,

- pri výsadbe v meste realizovat' výsadbu domácich druhov stromov a kríkov,

- strihanie živých plotov a kosenie priekop a verejných priestranstiev prispôsobit' termínovo hniezdeniu vtákov v týchto porastoch,

- zachovat' hniezda belorítok postavené na budovách, ktoré sú v správe či vlastníctve štátnych orgánov; vytvorit' pod hniezdami závesné podložky na zachytávanie trusu a predíst' tak jeho hromadeniu na parapetných doskách, chodníkoch a pod.; ukázat' tak občanom príklad spolunažívania človeka s prírodou,
- pret'ažené hniezda bociana bieleho odl'ahčit' odstránením hniezdneho materiálu a zabránit’ tak ich deštrukcii,

- podporit' osvetu a aktivity spojené s rozvešiavaním vtáčích búdok (stavebný úrad pri rekonštrukciách budov, školské zariadenia, záhradkári, dobrovol’né organizácie a i.),

- podporit' osvetu a aktivity pri zimnom prikrmovaní vtáctva inštaláciou kŕmidiel aj na verejných priestranstvách,

- obmedzit' výskyt túlavých mačiek a vol'ný pohyb psov v meste v hniezdnom období,

- vtáky sú zákonom chránené, preto nedopustit', aby dochádzalo $\mathrm{k}$ svojvol'nému zhadzovanie hniezd vtákov aspoň z budov, ktoré sú v správe štátu, resp. mesta,

- presklené plochy zabezpečit’ proti nárazom vtákov.

\section{Pod'akovanie}

Za podnetné pripomienky k rukopisu práce d'akujeme dvom recenzentom. Finalizovanie tejto štúdie bolo možné aj vd’aka finančnej podpore z projektu VEGA 2/0076/19 (BJ).

\section{Literatúra}

Anonymus 2020: Základné identifikačné údaje mesta Sabinov. —https://www.sabinov.sk/mesto-sabinov/21-omeste/30-zakladne-identifikacne-udaje-mesta-sabinov. Navštívené 7. 2. 2020.

Aronson M. F., La Sorte F. A., Nilon C. H., Katti M., Goddard M. A., Lepczyk C. A. ET AL. 2014: A global analysis of the impacts of urbanization on bird and plant diversity reveals key anthropogenic drivers. Proceedings of the Royal Society B: Biological Sciences 281(1780): 20133330.

BEJČEK V. \& ŠŤAsTnÝ K. 2014: Metodika Mapování hnízdního rozšíření ptáků v České republice (2014-2017). - Aythya 5: 48-52.

Beninde J., Veith M. \& HochKirch A. 2015: Biodiversity in cities needs space: a meta-analysis of factors determining intra-urban biodiversity variation. - Ecology Letters 18: 581-592.

Chace J. F., WALsh J. J. 2006: Urban effects on native avifauna: a review. - Landscape and Urban Planninng 74: 46-69. 
DANiš P. 2016: Děti venku v př́rodě: ohrožený druh? O významu kontaktu s přírodou pro zdraví a učení našich dětí. Ministerstvo životního prostředí ČR, Praha.

Danko Š., Lešo P., PJenčÁk P., Lipták J., Fulín M. et al. 2010: Vtáctvo Slanských vrchov a ich predhorí. Slovenská ornitologická spoločnost'/BirdLife Slovensko, Bratislava.

DARolová A. \& KrišTín A. 2002: Kačica divá (Anas platyrhynchos). - Pp.: 131-133. In.: DANKo, Š., DARolová A. \& KRIšTín A. (eds) 2002: Rozšírenie vtákov na Slovensku. Veda, Bratislava.

DeMeo T. E., Manning M. M., Rowland M. M., Vojta C. D., McKelvey K. S., Brewer C. K. et Al. 2013: Monitoring vegetation composition and structure as habitat attributes. - Pp.: 4-1-4-64. In: RowLAND M. M. \& Vojta C. D. (eds.): A technical guide for monitoring wildlife habitat. Gen. Tech. Rep. WO-89. US Department of Agriculture, Forest Service, Washington, DC.

Dormann C. F., Elith J., Bacher S., Buchmann C., Carl G., CARrÉ G. ET AL. 2013: Collinearity: a review of methods to deal with it and a simulation study evaluating their performance. - Ecography 36: 27-46.

Evans K. L., Newson S. E. \& Gaston K. J. 2009: Habitat influences on urban avian assemblages. - Ibis 151: 19-39.

Ferenc M., Sedláček O., Fuchs R., Dinetti M., FraisSinet M. \& Storch D. 2014a: Are cities different? Patterns of species richness and beta diversity of urban bird communities and regional species assemblages in Europe. - Global Ecology and Biogeography 23: 479-489.

Ferenc M., SedláčEk O. \& Fuchs R. 2014b: How to improve urban greenspace for woodland birds: site and local-scale determinants of bird species richness. Urban Ecosystems 17: 625-640.

Ferenc M., Sedláček O., Mourková J., Exnerová A., Š́opek J., Formánek J. \& Fuchs R. 2016: Disentangling the influences of habitat availability, heterogeneity and spatial position on the species richness and rarity of urban bird communities in a central European city. - Urban Ecosystems 19: 1265-1281.

Fey K., Vuorisalo T., Lehikoinen A. \& Selonen V. 2015: Urbanisation of the wood pigeon (Columba palumbus) in Finland. - Landscape and Urban Planning 134: 188-194.

Freemark K. E. \& Merriam H. G. 1986: Importance of area and habitat heterogeneity to bird assemblages in temperate forest fragments. - Biological Conservation 36: 115-141.
GiL D. \& Brumm H. (eds.) 2014: Avian urban ecology. Oxford University Press, Oxford.

Fuchs R., ŠKopek J., Formánek J. \& Exnerová A. 2002: Atlas hnízdního rozšírení ptáku Prahy. - Consult, Praha.

Hervé M. 2019: RVAideMemoire: Testing and plotting procedures for biostatistics. R package version 0.9-73. - https://cran.r-project.org/package=RVAideMemoire. Navštívené 7. 12. 2019.

IAnkov P. 2005: Sofia. - Pp.: 279-305. In: Kelcey J. G. \& Rheinwald G. (eds.): Birds in European cities. GinsterVerlag, St. Katharinen.

JAмвоR R. 2020: Vtáctvo Trenčína. - SOS/BirdLife Slovensko, Bratislava.

JoKIMÄKi J., SUHONEN J., JOKIMÄKI-KAISANLAHTI M. L. \& CARBó-RAmírez P. 2016a: Effects of urbanization on breeding birds in European towns: Impacts of species traits. — Urban Ecosystems 19: 1565-1577.

JокімÄкi J., SUHONEN J. \& KAISANLAhti-JokimÄKi M. L. 2016b: Urbanization and species occupancy frequency distribution patterns in core zone areas of European towns. - European Journal of Ecology 2: 23-43.

JokimÄKi J., SUhonen J. \& KaisAnlahti-Jokimäкi M. L. 2018: Urban core areas are important for species conservation: A European-level analysis of breeding bird species. - Landscape and Urban Planning 178: 73-81.

KARASKA D. 2002: Zelienka obyčajná (Carduelis chloris). Pp.: 604-606. Danko Š., Darolová A. \& KRišTín A. (eds.): Rozšírenie vtákov na Slovensku. Veda, Bratislava.

KAssambara A. 2019: ggpubr: ,ggplot2‘ based publication ready plots. $\mathrm{R}$ package version 0.2 .1 . - https://cran.rproject.org/package=ggpubr. Navštívené 7. 12. 2019.

Kelcey J. G. \& Rheinwald G. (eds.) 2005: Birds in European cities. Ginster-Verlag, St. Katharinen.

Kropil R. 2002: Drozd čierny (Turdus merula). - Pp.: 480-482. Danko Š., Darolová A. \& Krištín A. (eds.): Rozšírenie vtákov na Slovensku. - Veda, Bratislava.

Lepczyк C. A., La Sorte F. A., Aronson M. F., Goddard M. A., MacGregor-Fors I., Nilon C. H, \& Warren P. S. 2017: Global patterns and drivers of urban bird diversity. - Pp.: 13-33. In: Murgui E. \& Hedblom M. (eds.): Ecology and conservation of birds in urban environments. Springer, Cham.

Louv R. 2008: Last child in the woods. Algonquin Books, Chapel Hill.

MACGregor-Fors I. 2008: Relation between habitat attributes and bird richness in a western Mexico suburb. - Landscape and Urban Planning 84: 92-98. 
MACHÁčová K. 2016: Ptáci ve městech: Ekologické souvislosti a aktuální stav hnízdního rozšíření ptáků Brna. Bakalářská práce. - Př́rodovědecká fakulta, Masarykova univerzita, Barno.

Matisová S., Nagy B., Korytár L. \& Uhrin M. 2015: Poznámky k populácii dážd’ovníka obyčajného (Apus apus) v aglomerácii mesta Košice (V Slovensko). Tichodroma 27: 18-27.

Melles S., Glenn S. \& MaRtin K. 2003: Urban bird diversity and landscape complexity: Species-environment associations along a multiscale habitat gradient. Conservation Ecology 7(1): 5.

Michaeli E. 2000: Geografická poloha a vymedzenie územia. - Pp.: 9-13. In.: KóNYA P. (ed.): Dejiny Sabinova. Mestský úrad Sabinov, Sabinov.

MošAnský L. \& PAČEnovský S. 2014: Hniezdne spoločenstvá vtákov parkov a cintorínov mesta Košíc. - Parazitologický ústav SAV, Košice.

Navrátilová A. \& Trnka A. 2016. Hniezdenie holuba hrivnáka (Columba palumbus) v Trnave. - Tichodroma 28: 13-17.

NaKagawa S. \& CUThill I. C. 2007: Effect size, confidence interval and statistical significance: a practical guide for biologists. - Biological Reviews 82: 591-605.

Oksanen J., Blanchet F. G., Friendly M., Kindt R., LeGendre P., McGlinn D., Minchin P. R., O'Hara R. B., Simpson G. L., Solymos P., Stevens M. H. H., Szoecs E. \& WAGNER H 2018: Vegan: community ecology package. R package version 2.5-2. — https://cran.r-project. org/web/packages/vegan. Navštívené 13. 6. 2019.

PČola Š. 2012: Vtáctvo okresu Snina. — Slovenská ornitologická spoločnost'/BirdLife Slovensko, Bratislava.

SALAJ J. 1971: Omitocenóza obcí a ludských obydlí Poiplia. — Acta Facultatis Pedagogicae, Banská Bystrica: 65-81.

R Core Tелм 2019: R: A language and environment for statistical computing. - R Foundation for Statistical Computing, Vienna, Austria. — https://www.r-project. org/. Navštívené 13. 6. 2019.

SALAJ J. 1989: Vplyv lazníckeho osídlenia na zloženie omitocenóz v okolí Kokavy nad Rimavicou. - Biológia 44: 973-981.

Sandström U. G., Angelstam P. \& Mikusiński G. 2006: Ecological diversity of birds in relation to the structure of urban green space. - Landscape and Urban Planning 77: 39-53.

Seto K. C., Guneralp B., Hutyra L. R. 2012: Global forecasts of urban expansion to 2030 and direct impacts on biodiversity and carbon pools. - Proc Natl Acad Sci USA 109: 16083-16088.

Sol D., González-Lagos C., Moreira D., Maspons J. \& LAPIEDRA O. 2014: Urbanisation tolerance and the loss of avian diversity. — Ecology Letters 17: 942-950.

ŠolomekovÁ T. 2008: Vtáky štálového osídlenia v okolí Novej Bane (stredné Slovensko). - Tichodroma 20: 113-118.

ŠŤAstný K. \& Hudec K. (eds.) 2011: Ptáci 3. Fauna ČR. — Academie, Praha.

Steel E. A., Kennedy M. C., Cunningham P. G. \& StanoVICK J. S. 2013: Applied statistics in ecology: common pitfalls and simple solutions. - Ecosphere 4(9): 115.

Sychra J., Hudec K. \& ČERnÝ M. 2016: Mapování hnízdního rozšíření ptáků Brna v letech 2011 až 2016 - první výsledky. - Pp.: 38. In: KLvaŇová A. (ed.): „Každý pták se počítá“, Ornitologická konference 14.-16. 10. 2016, Mikulov. Sborník abstraktů. Česká společnost ornitologická, Praha.

ŠÚ SR 2019: Velkostné skupiny obcí - SR, oblasti, kraje, okresy, mesto, vidiek. StatDat. Verejná databáza údajov (5. 11. 2019). - Štatistický úrad Slovenskej republiky, Bratislava.

Tryjanowski P., Morelli F., Mikula P., Krištín A., InDy Kiewicz P., Grzywaczewski G., Kronenberg J. \& JERZAK L. 2017: Bird diversity in urban green space: a large-scale analysis of differences between parks and cemeteries in Central Europe. - Urban Forestry and Urban Greening 27: 264-271.

Urbanová S. \& Kocian L. 1997: Vtáčie spoločenstvá troch typov vidieckeho osídlenia na Slovensku. - Tichodroma 10: 110-126.

VYHLÁŠKA MŽP SR č. 24/2003 Z. Z., ktorou sa vykonáva zákon o ochrane prírody a krajiny č. 543/2002; Príloha č. 32 - Spoločenská hodnota druhov vtákov prirodzene sa vyskytujúcich na území SR.

WesoŁowski T. \& Fuller R. J. 2012: Spatial variation and temporal shifts in habitat use by birds at the European scale. - Pp.: 63 - 92. In: Fuller R. J. (ed.): Birds and habitat: relationships in changing landscapes. Cambridge University Press, Cambridge.

Došlo: 7. 2. 2020

Prijaté: 1. 4. 2020

Online: 3. 4. 2020 
Príloha 1. Vtáčie druhy, počet hniezdiacich párov zaznamenaných $v$ meste Sabinov a jeho zónach, ich dominancia $(\mathrm{D} \%)$, frekvencia výskytu $(\mathrm{F} \%)$, väzba na intravilán mesta, spôsob hniezdenia a hustota hniezdnych párov v prepočte na 10 ha. Zóny: 1. centrum mesta, 2. rodinné domy z 50. - 90. rokov, 3. rodinné domy od 90. rokov po súčasnost', 4. priemyselná čast' a dvor pol'nohospodárskeho podniku, 5. sídlisko, 6. športový areál a záhradky, 7. pás zelene, biokoridor mestom (obr. 1). Väzba na intravilán: 1 = druhy potravne aj hniezdením naviazané na urbánny habitat, 2 = druhy najmä hniezdením naviazané na urbánny habitat, 3 = druhy, ktorým habitat $v$ intraviláne nahrádza pôvodné prostredie, 4 = druhy, ktoré bežne $v$ urbánnom prostredí nehniezdia (pre viac informácií vid' Metodiku). Hniezdne stanovište / gildy: St = hniezdič na l'udských stavbách, Sm $=v$ korunách stromov, $\mathrm{Kr}=\mathrm{v}$ kríkoch, $\mathrm{Du}=\mathrm{v}$ dutinách stromov, $\mathrm{Zm}=$ na zemi či v bylinnom poraste a Sk = druhy hniezdiace v skalných puklinách a podobných dutinách pri vodných tokoch. Preferované hniezdne stanovište je tučným písmom.

Appendix 1. $\longrightarrow$ Bird species, number of nesting pairs recorded in the town Sabinov and its zones, nesting density, dominance $(D \%)$, frequency (F\%), their association to the urban area, and nesting site (nesting guild). Zones: $1=$ town centre, $2=$ an old detached houses' residential area (50s-90s of the $20^{\text {th }}$ century), $3=$ a recent detached houses' residential area (since 90 s of the $20^{\text {th }}$ century to present), $4=$ industrial zone, $5=$ a high-rise buildings' residential area, $6=$ gardening settlement and sports area, 7 = greenway (Fig. 1). Association to urban area: $1=$ species habitat- and nest-bound to urban habitat, $2=$ species mainly nest-bound to urban habitat, $3=$ species, which occupied habitats in the urban area resemble the original habitat, $4=$ species that are normally in urbanized environment question do not nest. Nest location: St = building-nesters, Sm = tree-crown-nesters, $\mathrm{K} r=$ shrub-nesters, $\mathrm{Du}=$ hole-nesters, $\mathrm{Zm}=$ ground-nesters, and Sk = riparian cavity-nesters. Preferred nest location is in bold. 


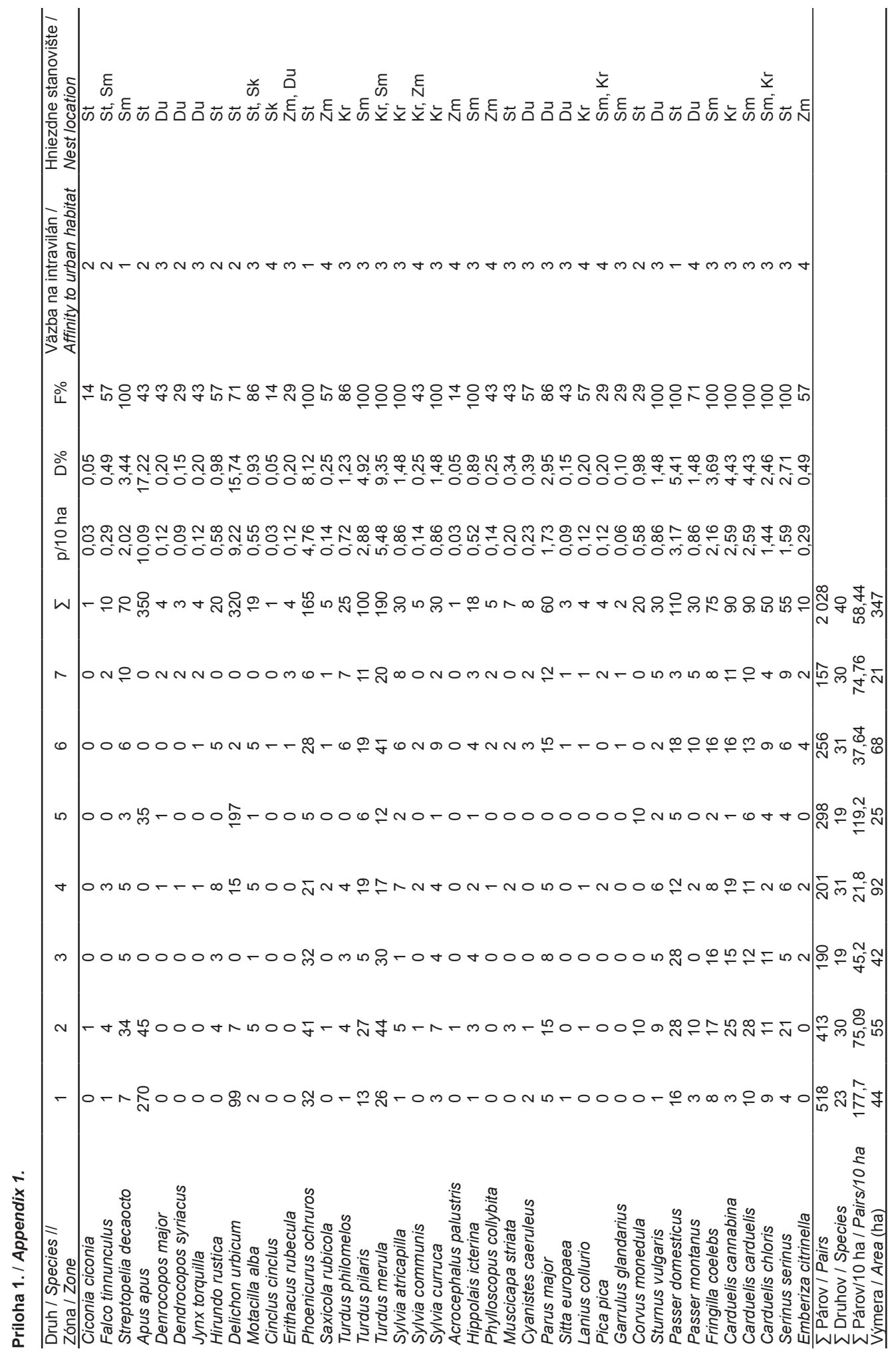


Príloha 2. Spearmanova korelačná matica pre charakteristiky zón mesta Sabinov. Pre zóny pozri príloha 1. Kurzíva = $\mathrm{P}<0,10,{ }^{*}=\mathrm{P}<0,05,{ }^{* *}=\mathrm{P}<0,01$.

Appendix 2. Spearman's correlation matrix for characteristics of Sabinov town zones. For zones see Appendix 1. Italics = $P<0.10,{ }^{*}=P<0.05,{ }^{* *}=P<0.01$.

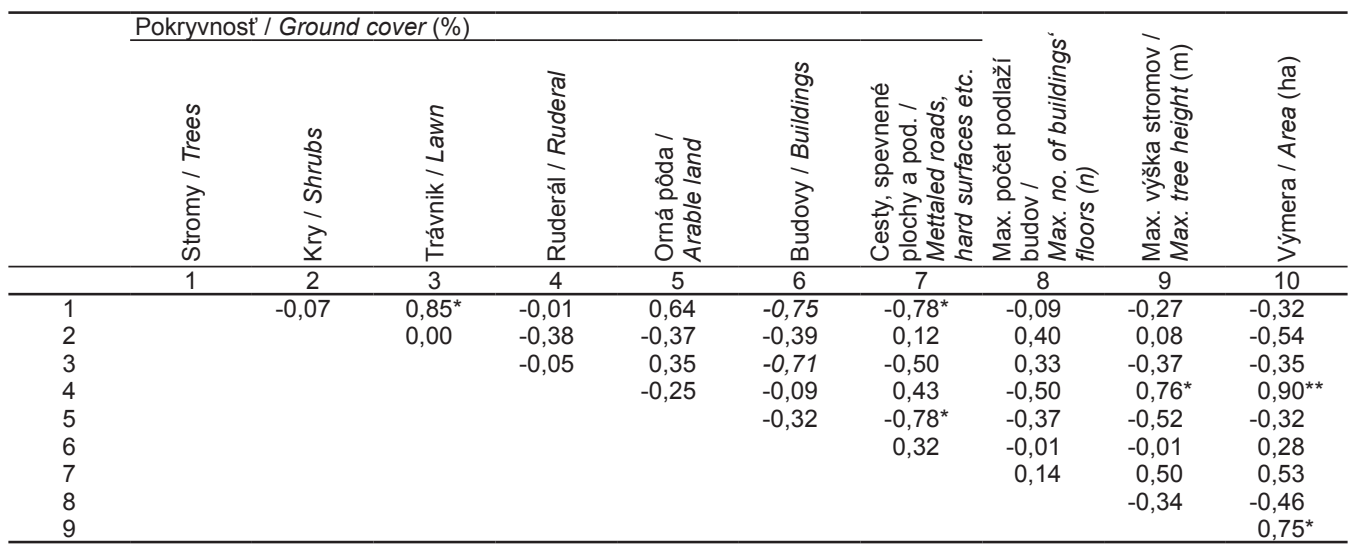

